\title{
Drugs and lipid metabolism
}

By A. S. Truswell, Nutrition Department, Queen Elizabeth College, Campden Hill, London $W 87 A H$

I propose to give a review of the effect of drugs on lipid metabolism which will be extensive rather than intensive. Several excellent reviews are available that discuss the drugs which are most effective for lowering plasma lipid levels in the six main types of human hyperlipoproteinaemia (Lees \& Wilson, 1971; British Medical Journal, 1972; Levy, Fredrickson, Shulman, Bilheimer, Breslow, Stone, Lux, Sloan, Krauss \& Herbert, 1972). But there are other drugs, not thought of as lipidlowering agents, that can decrease or increase one or more of the plasma lipids. I shall try to review these, and also some facets of lipid metabolism, other than plasma concentrations, as affected by drugs.

I shall restrict myself to drugs that are available and used in clinical medicine. If I were to include drugs that have been used to influence lipid metabolism in experimental animals or the new lipid-lowering drugs that are still at the stage of clinical trials and not yet approved, the list would be at least twice as long.

\section{Drugs that tend to cause malabsorption}

Most of the listed drugs in Table I can cause malabsorption of several nutrients, and steatorrhoea. A few have an effect mostly confined to fat absorption. Neomycin by mouth is the outstanding example of a drug that induces malabsorption. A variety of nutrients are affected, and mild morphological changes occur in the jejunal villi (Dobbins, I968). Oral kanamycin has the same effect, but to a lesser degree.

Colchicine, phenindione, $p$-aminosalicylic acid (PAS) and indomethacin can have similar effects (Dobbins, 1968; Kendall, Nutter \& Hawkins, 1971). Methotrexate, a folic acid antagonist, can produce morphological alterations in the intestinal mucosa, and diarrhoea and malabsorption have been reported following its use for psoriasis.

Chlortetracycline is an inhibitor of pancreatic lipase (Krondl, I970). Calcium salts in large doses can lead to precipitation of fatty acids in the intestinal lumen as insoluble Ca soaps (Yacowitz, Fleischman \& Bierenbaum, I965; Carlson, Olsson, Orö \& Rössner, 197I). Cholestyramine resin is, in therapy, used for its ability to bind bile acids, but it also binds several common acidic drugs (Gallo, Bailey \& Sheffner, 1965), and, in large doses, it can induce steatorrhoea in man (Hashim, Bergen \& Van Itallie, 1961), and loss of fat-soluble vitamins. Liquid paraffin used as a colonic lubricant can interfere with absorption of fat-soluble vitamins (Sinclair, 1967). 


\title{
Table I. Drugs that tend to cause malabsorption
}

\author{
Neomycin, kanamycin \\ Chlortetracycline \\ Colchicine \\ Phenindione \\ $p$-Aminosalicylic acid \\ Indomethacin \\ Methotrexate \\ Calcium salts \\ Cholestyramine resin \\ Liquid paraffin
}

\section{Drugs that increase faecal excretion of bile acids}

This is the principal therapeutic action of cholestyramine resin. The drug produces a consequent negative sterol balance, and a lowering of the plasma cholesterol concentration. It is at present considered the drug of choice for type IIA hyperlipoproteinaemia. Colestipol (U-26, 597A) is a newer drug of the same type (Parkinson, Gundersen \& Nelson, 1970). Eastwood \& Girdwood (r968) demonstrated that lignin has the property of sequestering bile acids, and a preparation has been used in Canada as a cholesterol-lowering agent (Thiffault, Bélanger \& Pouliot, 1970). Its effectiveness has, however, been questioned recently (Lindner \& Möller, I973). A hydrophilic colloid from psyllium seed, similar to preparations used as a bulk laxative, has been reported to increase faecal bile acids and to lower plasma cholesterol in man (Forestner, Forman, Garvin \& Taylor, r967). Howard \& Hyams (197r) found that diethylaminoethyl (DEAE) Sephadex, a resin better known in the laboratory than the dispensary, is an effective bile acid sequestrant; in a preliminary study it appeared to be somewhat more effective in lowering plasma cholesterol levels and more palatable than cholestyramine.

Neomycin has a cholesterol-lowering effect which is greater than would be expected from its property of producing a mild general malabsorption. It has been found that bile acids are precipitated in the gut by combination with the six basic groups in the molecule of this poorly absorbed aminoglycoside antibiotic (Thompson, MacMahon \& Claes, 1970).

Table 2. Drugs that increase faecal bile acids

\author{
Neomycin, kanamycin \\ Cholestyramine ('Questran') \\ Colestipol \\ Lignin \\ Colloid from psyllium seed \\ Diethylaminoethyl (DEAE) Sephadex
}

\section{Drugs that inhibit cholesterol absorption}

$\beta$-Sitosterol is the most abundant of the plant sterols in most of the edible vegetable oils (Itoh, Tamura \& Matsumoto, 1973). The amounts are relatively small, and much of it can be lost with other unsaponifiables during the purification procedures. In large doses ( $3 \mathrm{~g}$ or more 3 times daily before meals) it has been used in America, 
since the mid-fifties, as a pharmaceutical preparation to lower plasma cholesterol (Farquhar \& Sokolow, 1958). It appeared originally that $\beta$-sitosterol was not absorbed and was a competitive inhibitor of cholesterol absorption. However, modern analytical methods show that some of the phytosterols do get into the body (Ravi Subbiah, I973) and two cases have been reported of $\beta$-sitosterolaemia with xanthomatosis (Bhattacharyya \& Connor, 1973).

Two of the polyene macrolide antibiotics used as antifungal agents, amphotericin $B$ and candicidin, when given by mouth, lower plasma cholesterol levels in two animal species, with a concomitant increase in faecal sterols (Fisher, Griminger \& Schaffner, I969). It has lately been reported from Belgium that sulphaguanidine, a well-established sulphonamide much used for intestinal infections, specifically inhibits cholesterol absorption in rats and mice, and this effect is independent of any effect on the intestinal microflora because it is seen in germ-free animals (Eyssen, Vanderhaeghe \& de Somer, 1971). It would be interesting to know what effect it has in man.

\section{Table 3. Drugs that inhibit cholesteral absorption \\ $\beta$-Sitosterol ('Cytellin') \\ Sulphaguanidine \\ Amphotericin B \\ Candicidin}

\section{Drugs that affect lipoprotein lipase}

Once lipids are absorbed, they are carried into the circulation in chylomicrons, which consist mostly of triglyceride. The greater part of this triglyceride is taken up from the chylomicrons by adipose tissue (Redgrave, $197^{\circ}$ ) under the influence of lipoprotein lipase. As is well known, this lipaemia-clearing factor is stimulated by heparin. It is inhibited by injection of protamine sulphate (Korn, 1957) which antaganizes heparin. Lipoprotein lipase is potentiated by insulin in physiological amounts. Clearing of alimentary lipaemia is more rapid when the sugar taken with the fat is glucose rather than sucrose (Mann, Truswell \& Pimstone, 197r). Glucose is the more effective stimulant of insulin secretion.

Recent studies have shown that female sex hormones influence lipoprotein lipase, which can partly explain their effects on plasma lipids. Post-heparin lipoprotein lipase activity (PHLA) is reduced by oestrogens alone and by oestrogenprogestagen oral contraceptives (Hazzard, Spiger, Bagdade \& Bierman, I969). On the other hand the progestogen norethindrone acetate increases PHLA (Glueck, Brown, Levy, Greten \& Fredrickson, 1969) and so does the synthetic androgen oxandrolone (Glueck, Ford, Steiner \& Fallat, I973).

Table 4. Drugs that affect liprotein lipase
Heparin
Protamine sulphate
Insulin
Oestrogens
Oxandrolone
Norethindrone




\section{Drugs that can cause fatty liver}

By far the commonest of these is ethanol. Fatty liver can result from increased mobilization of free fatty acids (FFA) from adipose tissue, or increased fatty acid synthesis in the liver, or decreased oxidation of fatty acids in the liver or from decreased synthesis and release of lipoproteins from the liver. The fatty liver in alcoholics is associated with hypertriglyceridaemia, normal peripheral uptake of lipid and usually normal plasma FFA (Chait, Mancini, February \& Lewis, 1972) and there is clear experimental evidence that ethanol stimulates triglyceride fatty acid synthesis in the liver, presumably because of the excess $\mathrm{NADH}_{2}$ generated by oxidation of the ethanol (Hawkins \& Kalant, 1972). In man, fatty liver has been produced by giving alcohol to volunteers who received adequate vitamins and protein in their diets throughout the experiment (Lieber, Jones \& DeCarli, 1965). Epidemiologically, the finding of fatty liver appears to depend on the dose of ethanol consumed, rather than on the type of drink (Lelbach, I968).

Fatty liver has been found in patients given large doses of adrenal corticosteroids (Hill, I96x). Other drug-induced cases of fatty liver are few and far between. Acute fatty liver can occur when tetracycline is given intravenously in late pregnancy (Kunelis, Peters \& Edmonson, 1965). This is a serious complication of pregnancy. Tetracycline inhibits hepatic protein synthesis. Fatty liver can also occur as a toxic reaction to chloroform.

Most of the drugs which cause liver toxicity in man produce other histological features like cholestasis, inflammation or necrosis. The agents which have been used to produce experimental fatty liver in animals, such as ethionine, puromycin, carbon tetrachloride, yellow phosphorus, orotic acid, dimethylnitrosamine and cerous chloride, are not used therapeutically in man.

\section{Drugs that affect $F F A$ release from adipose tissue}

The drugs listed in Table 5 are those which have been reported to be active in man. A larger number affect lipolysis in adipose tissue in vitro or in animals. Pharmacological control of FFA release has been reviewed by Kupiecki (1971) and lipolysis in vitro by Fain (1973).

The catecholamines act primarily via $\beta$-adrenergic receptors and they activate adenyl cyclase, which in turn increases the concentration of cyclic AMP in the adipocyte and this stimulates the hormone-sensitive trigylceride lipase.

The methylxanthines cause accumulation of AMP by inhibiting phosphodiesterase ( $E C$ 3.I.4.I). A cup of instant coffee increases plasma FFA, but if sucrose is given with the coffee the FFA response is reduced (Bellet, Kershbaum \& Finck, 1968), possibly because insulin secretion is stimulated, and insulin is an inhibitor of lipolysis. It has been reported that caffeine-induced lipolysis is prevented by simultaneous food intake (Studlar, 1973).

Growth hormone and adrenocorticotrophic hormone stimulate FFA release, but after a lag of 2 or $3 \mathrm{~h}$. In vitro experiments indicate that synthesis of an intermediary protein, which then acts on adenyl cyclase, is probably stimulated. 
Glugagon has recently been shown to stimulate lipolysis provided its insulinotropic effect can be prevented (Marks, 1973). In man this was achieved by infusing minute amounts after $3 \mathrm{~d}$ without food.

The appetite suppressants and several psychotropic drugs increase FFA release.

The best known inhibitor of lipolysis is nicotinic acid. It depresses both basal and catecholamine-induced lipolysis. Nicotinamide is ineffective. Nicotinic acid appears to be a non-specific inhibitor of adenyl cyclase. This action may be the basis for the lipid-lowering action of nicotinic acid. Several chemically related compounds have a similar action. An analogue, 5-fluoro-3-hydroxymethylpyridine hydrochloride (metabolized to 5-fluoro-nicotinic acid), which does not cause the flushing that is a troublesome side-effect with nicotinic acid, lowered FFA in patients who had had a myocardial infarction (Rowe, Dolder, Kirby \& Oliver, 1973). This may make it a useful drug because there is evidence that increased FFA release after myocardial infarction may predispose to arrhythmias (Kurien \& Oliver, 1971).

Propranolol and related drugs appear to prevent catecholamine-induced lipolysis by their $\beta$-adrenergic blocking action. It is generally agreed that the receptor mediating the release of FFA by sympathomimetic amines in man is a $\beta$-receptor.

Insulin is an important physiological inhibitor of adipose tissue lipolysis. Prostaglandin $E_{1}$ is only one-hundredth as active on a molar basis. Its effect in man depends on the source of adipose tissue and on other conditions. Further work will be needed to show whether it plays a physiological role.

\section{Table 5. Drugs that affect free fatty acid release from adipose tissue}

Increase lipolysis
Adrenaline
Noradrenaline
Isoprenaline
Theophylline
Caffeine
Aminophylline
Growth hormone
Adrenocorticotrophic hormone
Glucagon
Thyroxine
Amphetamine
Fenfluramine
Chlorpromazine
Amitriptyline
Fat-mobilizing substance

Decrease lipolysis

Nicotinic acid

B-Pyridyl carbinol (Ronicol)

5-Fluoronicotinic acid derivative

Propranolol etc.

Insulin

Prostaglandin $\mathrm{E}_{1}$

Salicylates

Sulphonylureas

Biguanides

Clofibrate

\section{Drugs which lower plasma lipid concentrations}

The first group of drugs shown in Table 6 are used specifically to lower plasma lipid concentrations. Since some have more effect on low-density lipoproteins (LDL) or cholesterol, and others on very-low-density lipoproteins (VLDL) or endogenous triglycerides, different drugs are appropriate for the different types of hyperlipoproteinaemia. No drug is of value in the rare Type I hyperlipoproteinaemia. For Type II, cholestyramine is probably the drug of choice at present. It reduces plasma cholesterol and not VLDL. An alternative is D-thyroxine, which increases hepatic 
cholesterol catabolism (Rabinowitz, Rodman \& Myerson, 1963) with relatively little of the thermogenic effect of the L-isomer.

Clofibrate ('Atromid') is quite a useful drug in Type IIb. More research has been done on clofibrate than on any of the other lipid-lowering agents, yet the picture of its mechanism of action is confusing. Thorp ( 1963 ), who introduced it, originally suggested that it acted by displacing thyroxine from its binding to plasma albumin, with a consequent increase of free thyroxine in the liver. But thyroid hormones reduce mainly LDL, while clofibrate has more effect on VLDL. Thyroid hormones affect the glycine: taurine conjugation ratio of biliary bile acids, but clofibrate does not (Truswell, Mitchell \& McVeigh, r 966), and it was later shown, using [131I]thyroxine, that the hepatic content of thyroxine and plasma-to-liver flux are not increased in patients taking clofibrate (Musa, Ogilvie \& Dowling, 1968). Hepatic triglyceride synthesis appears to be decreased in rats (Adams, Webb \& Fallon, 1971); on the other hand, recent experiments in man suggest increased clearance of triglycerides from the blood (Wolfe, Kane, Havel \& Brewster, 1973).

Clofibrate is also the drug of choice for the uncommon Type III hyperlipoproteinaemia. It is very effective too in the common Type IV. An alternative for Type IV is nicotinic acid, which has been used as a lipid-lowering agent since 1955 . The dose is a pharmacological one, $3 \mathrm{~g}$ or more per $\mathrm{d}$ by mouth, not a vitamin dose. The principal mechanism for its effect appears to be its striking inhibitory effect on lipolysis in adipose tissue (Dalton, Kowalski, Mallon \& Marschhaus, 1968). Carlson \& Orö (1973) have reported their experience of its effectiveness in the different types of hyperlipoproteinaemia. Nicotinamide is ineffective.

Clofibrate and nicotinic acid are effective in Type V mixed hypertriglyceridaemia. In addition norethindrone (norethisterone) acetate, a progestin, is effective in the familial variety of Type V (Glueck et al. 1969).

The first cholesterol-lowering drugs used in secondary prevention trials of coronary heart disease were oestrogens: ethinyl oestradiol (Oliver \& Boyd, I961) or 'premarin' (Stamler, Pick, Katz, Pick, Kaplan, Berkson \& Century, r963). They lower plasma cholesterol in men, but their side-effects are rather unacceptable now that we have a wider choice of lipid-lowering agents. Plasma triglycerides were not measured in the early trials. Physiological doses of oestrogens may have a place (not only for reducing plasma cholesterol) in post-menopausal women, but triglycerides can be increased though cholesterol falls (Robinson \& LeBeau, 1965). In some studies the reduction of cholesterol was unimpressive (Utian, 197I).

Although plasma lipid levels are higher in men than in women, methyl testosterone, which is effective by mouth, was reported to lower plasma cholesterol in animals. In man methyl testosterone usually causes a small reduction in $\alpha$-lipoprotein cholesterol but a rather larger increase in LDL cholesterol. However, in one case of hypertriglyceridaemia, there was a dramatic fall of plasma triglycerides (Robinson, LeBeau \& Cohen, 1964). Since then several of the related newer anabolic steroids have been reported to lower levels of plasma lipids, usually triglycerides, e.g. oxandrolone, stanozolol and drostanolone. It appears that there is no close correlation between androgenic, anabolic and lipid-lowering effects. 


\section{Table 6. Drugs that lower plasma lipid concentrations}

(The lipids most affected are given in parentheses)

Clofibrate (TG \& chol)

Cholestyramine (chol)

Nicotinic acid (chol \& TG)

D-'Thyroxine (chol>TG)

Neomycin (chol $>$ TG)

Oestrogens (chol)

Norethindrone (TG)

Methyltestosterone derivatives (TG)

\author{
Aspirin and $p$-aminosalicylic acid \\ L-Asparaginase \\ 6-Azauridine \\ Calcium salts \\ Chenodeoxycholic acid \\ Chlortetracycline \\ Colchicine \\ Dextrans \\ Fenfluramine \\ Glucagon \\ Phenformin \\ Phenindione and diphenadione \\ Sulphinpyrazone \\ Trifluperidol \\ Tryptophan
}

TG, triglyceride; chol, cholesterol.

The remaining drugs in Table 6 are used for other conditions but have been noticed incidentally to lower plasma lipid levels. Aspirin lowers plasma cholesterol if given in large doses (Eidlitz, 1960) and PAS lowers cholesterol and triglyceride levels (Rytkonen, I969). Chlortetracycline has been reported to lower plasma cholesterol by 10\% (Samuel \& Waithe, 196r). Oral Ca salts, $\mathrm{I}-2 \mathrm{~g}$ daily, reduce plasma cholesterol (Carlson et al. 1971; Bierenbaum, Fleischman \& Raichelson, 1972). Colchicine lowers plasma cholesterol (Rubulis, Rubert \& Faloon, 1970). Infusions of dextrans can produce large falls of plasma cholesterol (Ditzel \& Dyerberg, 1969). Fenfluramine lowers plasma triglycerides (Pawan, 1969) but this may result from negative energy balance. Glucagon lowers both cholesterol and trigylceride levels (Caren \& Corbo, 1970). Phenformin administration is often accompanied by a reduction of plasma cholesterol, even in non-diabetics (Hocking, Chakrabarti, Evans \& Fearnley, I967; Hart \& Cohen, 1970). Phenindione accelerates the clearing of alimentary lipaemia (Fullerton \& McDonald, I961) and fasting plasma lipids are reduced in animals on diphenadione (Coon \& Willis, I970). Reduction of plasma cholesterol and triglycerides may occur in patients on propranolol (Wegner, Gebhardt \& Clotten, 1969). Plasma cholesterol falls significantly in patients given the tranquillizer trifluperidol (Clark, Braun, Hewson, Serafetinides, Colmore \& Rahhal, 1968) but not the related haloperidol. The uricosuric agent sulphinpyrazone has some cholesterol-lowering effect in gouty patients (Kuzell, Glover, Gibbs \& Blau, I964).

Among some newer and less common drugs, two that have been used in leukaemia were both associated with dramatic falls of plasma cholesterol: L-asparaginase (Astaldi, Micu \& Micu, I970) and 6-azauridine (Buttoo, Israëls \& Wilkinson, 1965). Tryptophan has recently been reported to lower the hyperlipidaemia of the nephrotic syndrome (Schapel, Edwards \& Neale, 1974). Chenodeoxycholic acid, which is under trial for medical treatment of gallstones, appears to lower plasma triglycerides (Bell, Lewis, Petrie \& Dowling, r973). 
Some drugs that can increase plasma lipid concentrations

These are shown in Table 7 .

Oral contraceptives of the oestrogen-progestogen type tend to increase fasting plasma triglycerides and, to a somewhat smaller extent, cholesterol. The effects vary with the preparation used. The most oestrogenic pills give the highest triglyceride values and the most progestational the highest cholesterol (Stokes \& Wynn, 1971). Some of the progestogen-only preparations do not appear to increase plasma lipids (Lancet, I97I).

Adrenal corticosteroids in large doses can induce lipaemia, with an increase of VLDL and of triglycerides more than cholesterol (Bagdade, Porte $\&$ Bierman, 1970; El-Shaboury \& Hayes, r973).

Chlorpromazine, when given in large dosage to psychiatric patients, increases plasma cholesterol (Clark, I967). Alcoholic lipaemia is discussed above. Thiouracil increases plasma cholesterol by its anti-thyroid action.

Growth hormone injection can raise plasma triglyceride levels in man; the effect is more marked in diabetic patients than normal subjects (Azizi, Castelli, Raben \& Mitchell, 1973).

\section{Table 7. Drugs that can increase plasma lipid concentrations}

(The lipids most affected are given in parentheses)

Oral contraceptives (TG \& chol)

Adrenal corticosteroids (TG)

Ethanol (TG)

Chlorpromazine (chol)

Thiouracil (chol)

Growth hormone (TG)

Vitamin D (chol)

Lindane and DDT ( $a-$ LP)

$$
\text { TG, triglyceride; chol, cholesterol; } a-L P \text {, } a \text {-lipoprotein. }
$$

The relationship between plasma cholesterol and vitamin $D$ first became known when hypercholesterolaemia was found to be a feature of infantile hypercalcaemia (Schlesinger, Butler \& Black, 1956). Golubović-Curčić \& Curčić (1973) reported that plasma cholesterol rises when children with rickets are treated with therapeutic doses of cholecalciferol. In normal subjects increased plasma cholesterol has been reported after administration of cholecalciferol by some investigators (Fleischman, Bierenbaum, Raichelson, Hayton \& Watson, 1970) but not by others (Carlson, Derblom \& Lanner, 1970).

Lastly I have included chlorinated hydrocarbon insecticides because, unlike almost all other agents, they have been reported to affect plasma high-density or $\alpha$-lipoproteins. Most agents that affect plasma cholesterol act on LDL (Franzini \& Schivi, 1964) but men exposed occupationally to $\gamma$-hexachlorocyclohexane (lindane) and DDT have been found to have hyper- $\alpha$-lipoproteinaemia (Carlson \& KolmodinHedman, 1972). 


\section{REFERENCES}

Adams, L. L., Webb, W. W. \& Fallon, H. J. (1971). J. clin. Invest. 50, 2339.

Astaldi, G., Micu, D. \& Micu, M. (1970). Lancet i, III3.

Azizi, F., Castelli, W. P., Raben, M. S. \& Mitchell, M. L. (1973). Proc. Soc. exp. Biol. Med. $143, \times 187$.

Bagdade, J. D., Porte, D. Jr \& Bierman, E. L. (1970). Archs intern. Med. 125, 129.

Bell, G. D., Lewis, B., Petrie, A. \& Dowling, R. H. (I973). Br. med. J. iii, 520.

Bellet, S., Kershbaum, A. \& Finck, E. M. (1968). Metabolism 17, 702.

Bhattacharyya, A. K. \& Connor, W. E. (r973). F. clin. Invest. 52, 9a.

Bierenbaum, M. L., Fleischman, A. I. \& Raichelson, R. I. (1972). Lipids 7, 202.

British Medical Journal (1972). Br. med. \%. ii, 642 .

Buttoo, A. S., Israëls, M. C. G. \& Wilkinson, J. F. (1965). Br. med. F. i, 552.

Caren, R. \& Corbo, L. (1970). Metabolism 19, 598.

Carlson, L. A., Derblom, H. \& Lanner, A. (1970). Atherosclerosis 12, 313.

Carlson, L. A. \& Kolmodin-Hedman, B. (1972). Acta med, scand. r92, 29.

Carlson, L. A., Olsson, A. G., Orö, L. \& Rössner, S. (1971). Atherosclerosis 14, 391.

Carlson, L. A. \& Orö, L. (1973). Atherosclerosis 18, 1.

Chait, A., Mancini, M., February, A. W. \& Lewis, B. (1972). Lancet ii, 62.

Clark, M. L. (I967). Psychosom. Med. 29, 634.

Clark, M. L., Braun, G. A., Hewson, J. R., Serafetinides, E. A., Colmore, J. P. \& Rahhal, D. K. (1968). Clin. Pharmac. Ther. 9, 333 .

Coon, W. W. \& Willis, P. W. 3rd (1970). Clin, Pharmac. Ther, II, 312.

Dalton, C., Kowalski, C., Mallon, J. \& Marschhaus, C. (1968). F. Atheroscler. Res, 8, 265.

Ditzel, J. \& Dyerberg, J. (1969). Atherosclerosis Io, 5.

Dobbins, W. O. (1968). Gastroenterology 54, 1193.

Eastwood, M. A. \& Girdwood, R. H. (1968). Lancet ii, 1170.

Eidlitz, M. (1960). Lancet ii, 1123.

El-Shaboury, A. H. \& Hayes, T. M. (1973). Br. med. \%. ii, 85.

Eyssen, H., Vanderhaeghe, H. \& de Somer, P. (I 97r). Fedn Proc. Fedn Am. Socs exp. Biol. $30,1803$. Fain, J. N. (r973). Pharmac. Rev. 25, 67.

Farquhar, J. W. \& Sokolow, M. (1958). Circulation $x_{7}, 890$.

Fisher, H., Griminger, P. \& Schaffner, C. P. (1969). Proc. Soc. exp. Biol. Med. r32, 253.

Fleischman, A. I., Bierenbaum, M. L., Raichelson, R., Hayton, T. \& Watson, P. (1970). In Atherosclerosis : Proceedings of the and International Symposium p. 468 [R. J. Jones, editor]. Heidelberg and New York: Springer-Verlag.

Forestner, J. E., Forman, D. T., Garvin, J. E. \& Taylor, C. B. (1967). F. Lab. clin. Med. 70, 863. Franzini, C. \& Schivi, T. (1964). Clinica Chim. Acta 9, 87.

Fullerton, H. W. \& McDonald, G. A. (I96r). Lancet i, 1169.

Gallo, D. G., Bailey, K. R. \& Sheffner, A. L. (1965). Proc. Soc. exp. Biol. Med. r20, 6o.

Glueck, C. J., Brown, W. V., Levy, R. I., Greten, H. \& Fredrickson, D. S. (1969). Lancet i, 1290.

Glueck, C. J., Ford, S., Steiner, P. \& Fallat, R. (1973). Metabolism 22, 807.

Grolubović-Curčić, V. \& Curčić, B. (1973). European Nutr. Conf., Cambridge Abstr. p. 57.

Hart, A. \& Cohen, H. (r970). Br. med. F. i, 22.

Hashim, S. A., Bergen, S. S. Jr \& Van Itallie, T. B. (196r). Proc. Soc. exp. Biol. Med. 106, 173.

Hawkins, R. D. \& Kalant, H. (1972). Pharmac. Rev, 24, 67.

Hazzard, W. R., Spiger, M. J., Bagdade, J. D. \& Bierman, E. L. (I969). New Engl. F. Med. 280, 471.

Hill, R. B. Jr (1961). New Engl. F. Med. 265, 318.

Hocking, E. D., Chakrabarti, R., Evans, J. \& Fearnley, G. R. (1967). Y. Atheroscler. Res. 7, 121.

Howard, A. N. \& Hyams, D. E. (I97I). Br. med. $\mathcal{Y}$. iii, 25.

Itoh, T., Tamura, T. \& Matsumoto, T. (1973). $¥$. Am. Oil Chem. Soc. 50, 122.

Kendall, M. J., Nutter, S. \& Hawkins, C. F. (I971). Br. med. $\mathcal{F}$. i, 533.

Korn, E. D. (I957). F. biol. Chem. 226, 827.

Krondl, A. (г970). Can. med. Ass. F. 103, 360.

Kunelis, C. T., Peters, J. L. \& Edmondson, H. A. (1965). Am. \%. Med. 38, 359.

Kupiecki, F. P. (1971). Prog. Biochem. Pharmac. 6, 274.

Kurien, V. A. \& Oliver, M. F. (1971). Prog. cardiovasc. Dis. 13, 36r.

Kuzell, W. C., Glover, R. P., Gibbs, J. O. \& Blau, R. A. (1964). Am. f. med. Sci. 248, 164.

Lancet (1971). Lancet i, 25.

Lecs, R. S. \& Wilson, D. E. (1971). New Engl. F. Med. 284, 186.

Lelbach, W. K. (1968). Germ. med. Mon. г3, 3 r.

Levy, R. I., Fredrickson, D. S., Shulman, R., Bilheimer, D. W., Breslow, J. L., Stone, N. J., Lux, S. E., Sloan, H. R., Krauss, R. M. \& Herbert, P. N. (1972). Ann. intern. Med. 77, 267.

Lieber, C. S., Jones, D. P. \& DeCarli, L. M. (1965). F. clin. Invest. 44, 1009.

33 (3) 3 
Lindner, P. \& Möller, B. (1973). Lancet ii, 1259.

Mann, J. I., Truswell, A. S. \& Pimstone, B. L. (1971). Clin. Sci. 41, 123.

Marks, V. (1973). Post-grad. med. J. 49, 6r5.

Musa, B. U., Ogilvie, J. T. \& Dowling, J. T. (1968). Metabolism 17, 909.

Oliver, M. F. \& Boyd, G. S. (I96I). Lancet ii, 499 .

Parkinson, T. M., Gundersen, K. \& Nelson, N. A. (I970). Atherosclerasis Ir, 53 I.

Pawan, G. L. S. (r969). Lancet i, 498.

Rabinowitz, J. L., Rodman, T. \& Myerson, R. M. (1963). F. Am. med. Ass, 183, 758.

Ravi Subbiah, M. T. (1973). Am. F. clin. Nutr. 26, 219.

Redgrave, T. G. (1970). F. clin. Invest. 49, 465.

Robinson, R. W. \& LeBeau, R. J. (1965). F. Atheroscler. Res. 5, Izo.

Robinson, R. W., LeBeau, R. J. \& Cohen, W. D. (1964). F. clin. Endocr. Metab. 24, 708.

Rowe, M. J., Dolder, M. A., Kirby, B. J. \& Oliver, M. F. (1973). Lancet ii, 814.

Rubulis, A., Rubert, M. \& Faloon, W. W. (1970). Am. F. clin. Nutr. 23, r251.

Rytkonen, R. (1969). Acta med. scand. 186, 539 .

Samuel, P. \& Waithe, W. I. (I961). Circulation 24, 578.

Schapel, G. J., Edwards, K. D. G. \& Neale, F. C. (1974). Prog. Biochem. Pharmac. 9, x.

Schlesinger, B. E., Butler, N. R. \& Black, J. A. (1956). Br. med. f. i, I27.

Sinclair, L. (1967). Lancet i, 792.

Stamler, J., Pick, R., Katz, L. N., Pick, A., Kaplan, B. M., Berkson, D. M. \& Century, D. (1963). F. Am. med. Ass. 183, 632 .

Stokes, T. \& Wynn, V. (1971). Lancet ii, 677 .

Studlar, M. (1973). F. nutr. Sci. 12, 109.

Thiffault, C., Bélanger, M. \& Pouliot, M. (1970). Can. med. Ass. f. 103, I65.

Thompson, G. R., MacMahon, M. \& Claes, P. (1970). Eur. F. clin. Invest. 1, 40.

Thorp, J. M. (1963). Y. Atheroscler. Res. 3, 35r.

Truswell, A. S., Mitchell, W. D. \& McVeigh, S. (1966). F. Atheroscler. Res. 6, 591,

Utian, W. H. (I97I). S. Afr. med. F. 45, 359.

Wegner, M., Gebhardt, W. \& Clotten, R. (1969). Dt. med. Wschr. 94, 904.

Wolfe, B. M., Kane, J. P., Havel, R. J. \& Brewster, H. P. (I973). F. clin. Invest. 52, 2146.

Yacowitz, H., Fleischman, A. I. \& Bierenbaum, M. L. (1965). Br. med. F. i, I352. 